\title{
The Use of Indexes for Trending in Engineering Valuation
}

\author{
Rowland J. O Ekeocha ${ }^{1}$
}

${ }^{1}$ Mechanical Engineering Department, Covenant University, Ota

\begin{abstract}
Three types of indexes are indicated in this write up namely cost, mathematical and catalog indexes. Cost indexes are used for trending in engineering valuation. A cost index is defined as a dimensionless number used to trend the cost of an item from one time period to another. It is also a ratio of the real price in a given time period against that of a selected base period multiplied by 100. Trending which is one of the methods used in engineering valuation is the application of an index factor to the historical cost of an item in order to estimate the current cost of the item and vice versa. This application is demonstrated in this article. Additional examples on trending are indicated in the supplementary exercises at the end of the article. Indexes are meant to serve as guide and should not be used if more reliable methods are available. Appraisers must therefore exercise caution and good judgment in their use.
\end{abstract}

Keywords: Indexes, Trending, Engineering Valuation

\section{Introduction}

The types of indexes include cost indexes, mathematical indices and catalog index.

Cost indexes_ A cost index is a dimensionless number used to adjust the cost of an item from one time period to another. The adjustment is necessary because of the changing value of money with time (Humphreys, 1991). A cost index is also the ratio of the actual price in a time period compared to that in a selected base period (a defined point in time or the average price in a certain year), multiplied by 100 (Wikipedia, 2019).

\section{Mathematical indices}

An index number is a number which is raised to a power. The power which is known as the index tells you the number of times you have to multiply the number by itself. For example, $2^{5}$ means that you have to multiply 2 by itself five times. That is $2 \times 2 \times 2 \times 2 \times 2=32$.

There are six laws of indices. The first law of indices states that when multiplying two identical numbers with different powers, the answers will be the same number to the power of both exponents added together. That is $2^{2} \times 2^{3}=2^{5}=32$. The laws expressed mathematical are as follows (http://m/youtube.com.watch).

\begin{tabular}{|c|c|c|}
\hline$x^{0}$ & $=$ & 1 \\
\hline$x^{-n}$ & $=$ & $\frac{1}{x} \mathrm{n}$ \\
\hline$x^{\mathrm{n}}$ & $x$ & $x^{\mathrm{m}}=x^{\mathrm{n}+\mathrm{m}}$ \\
\hline $\begin{array}{l}x^{\mathrm{n}} \div \\
\left(x^{\mathrm{n}}\right)^{\mathrm{m}}\end{array}$ & $\begin{array}{l}x^{\mathrm{m}} \\
=x^{\mathrm{nm}}\end{array}$ & $=x^{\mathrm{n}-\mathrm{m}}$ \\
\hline$x^{\mathrm{n} / \mathrm{m}}$ & $=$ & $\sqrt[m]{x^{n}}$ \\
\hline
\end{tabular}

\section{Catalog index}

This is a list of words or phrases and associated pointers to where useful materials relating to that heading can be found in a document or collection of documents. Examples are an index in the back matter of a book and an index that serves as a library catalog (Wikipedia, 2019).

\section{Trending in Engineering Valuation}

We are interested in cost indexes for engineering valuation. Cost indexes are used in trending. Trending is a method of pricing whereby an index factor is applied to the historical cost of an item in order to estimate the current cost of the item. When applying an index factor to trend the historical cost, the resulting trended cost represents the production cost new of the trended asset, not necessarily the replacement cost. Trending is therefore one of the methods adopted in engineering valuation.

Engineering valuation is the estimation of the monetary worth of a class of tangible assets that are held by a company for use in the production or supply of goods and services, for rental by others or for administrative purposes and expected to be used over a long period of time. Company assets include Plant and machinery, Vehicles, Land \& buildings and Furniture/ Fixtures. (IACE, 2019)

\section{Sources and uses of cost indexes}

The sources and usefulness of cost indexes are presented as follows: Majority of indexes are developed using standard mix of costs of an asset within a typical classification and/or industry. Therefore, the use of an index in trending may or may not produce the actual value of a specific item. In other words, the specific asset value may not be

This article is published under the terms of the Creative Commons Attribution License 4.0 Author(s) retain the copyright of this article. Publication rights with Alkhaer Publications. Published at: http://www.ijsciences.com/pub/issue/2020-03/

DOI: 10.18483/ijSci.2289; Online ISSN: 2305-3925; Print ISSN: 2410-4477 
accurate. However, the total value of all the assets may be reasonably correct. Indexes are designed to include many cost related factors. It therefore requires sound professional judgment as well knowledge of the source and limitations of the index in applying same. Representative sources for index data include the Bureau of labour statistics of the US Department of Labour, R.S. Means Company, Marshall Valuation Services and other national and regional sources like the Central Bank of Nigeria and the National Bureau of Statistics.

Machinery and equipment indexes are not sufficient as those for some industries such as construction. However, information can be found in many trade magazines such as American Machinist, Chemist Engineering, Engineering New Records (ENR) (Quarterly reports), Iron Age, and Oil \& Gas Journal. Some of these magazines actually publish an index while other produce information that must be posted from which an index may be developed. Additional index information for machinery and equipment is available from sources like Handy-Whitman (for public utilities), Statistics Canada (Ottawa), and the US Department of Labour (Producer Price Indexes).Finally, individual appraisers and appraisal firms can develop indexes to suit their own special needs as done by many insurance companies and engineering firms.

\section{Application of an index}

An index may be a useful tool in estimating the current cost of a machine from its historical cost. This is known as cost trending. Conversely, the same index may be used to estimate the historical cost when the current cost is known. This is sometimes referred to as reversed trending.

Example 1: To illustrate the use of an index to update the cost of a heat-treating furnace manufactured by a company in 1988 for $\$ 10,000$. The problem is to determine the cost of the same oven (furnace) in 1995. Assume we have developed the subsequent indexes based on the manufacturer's actual price increase over years, considering that no technological improvements occurred.

\begin{tabular}{|l|l|}
\hline Year & Index \\
\hline 1985 & 229 \\
\hline 1986 & 234 \\
\hline 1987 & 240 \\
\hline 1988 & 251 \\
\hline 1989 & 286 \\
\hline 1990 & 307 \\
\hline 1991 & 322 \\
\hline 1992 & 341 \\
\hline 1993 & 349 \\
\hline 1994 & 367 \\
\hline 1995 & 390 \\
\hline
\end{tabular}

Solution: Find the change over time by using the differences in the

annual indexes or

Current index $(1995) \div$ Historical index $(1988)=$ Trend Factor

Trend factor $\mathrm{x}$ Historical cost $=$ Current cost $(390 \div 251) \times 10000=1.5538 \times 10000=\$ 15538$

Example 2: A project was built in 1986 at a cost of $\$ 750 \mathrm{~m}$

The index for this project in 1986 was 238. What would be the project cost in 1989 if the index is 320 in 1989 ?

Solution: $\quad \frac{320}{238} \times 750 \mathrm{~m}=\$ 1008 \mathrm{~m}$

All indexes are calculated from a base year and vary depending on the index and when it began. To convert all indexes to a common base year, one may use the following relationship

Index value on new base = $\frac{\text { index value (Old base) to be converted }}{\text { index value (Old base for new base year }} \times 100$

Example 3: Convert the ENR Building cost index of March 1989 based on $1913=100$ to a base year of 1967. The index for March 1989 is 2616 and 676 for 1967 based on 1913 = 100 (Engineering New Record, ENR).

Solution: The Index value for the new base year (1967 average value) on the old base year $(1913=100)$ is 676 $\frac{2616}{676} \times 100=387$, ENR Building Cost Index for march $1989(1967=100)$

\section{Limitations of indexes}

Indexes are established for many different purposes. Their use may lead to erroneous result unless the appraiser is aware of the purpose for which the index was developed and the weightings or the mix used in developing the index.

For example, if functional obsolescence was considered when the index was prepared, an appraiser has to be aware of this fact, especially during the determination of the overall price changes without allowing for design modifications.

An index entitled machine shop may be presumed to reflect overall price changes in metal cutting machinery only if the percentage of the total weighting assigned to milling machines, drills, 
grinders, numerical control turning machine is considered. If such an index is used to trend the cost of the entire machine shop with the appropriate mix of the shop in question, then the resulting trended total cost would probably be reasonable. However, if the same index was used to trend the cost of an individual machine, the result might well be incorrect by a large percentage.

\section{Conclusion}

Remember that an index represents average changes in cost. The broader the index, the more average costs are used.

Indexes are meant to serve as guide and should not be used if more reliable methods are available. Appraisers must therefore exercise caution and good judgment in their use.

In the periods of rapid inflation, it is not advisable to trend prices from a broad-based index for period longer than five years without comparing the trended results against other sources.

It is important when using indexes to be certain that the proper index is applied. Indexes are designed to measure relative cost changes for various items over time and generally will give erroneous results if applied to something else.

\section{References}

1. Humphreys, K. K. (1991), Jelen's Cost and Optimization Engineering, Third Edition, Chapter 14, McGraw Hill Inc.

2. Indexes: Available from Wikipedia, 2019: https://en.wikipedia.org/wiki/Indexes

3. Institute of Appraisers and Cost Engineers (IACE) of the Nigerian Society of Engineers (NSE), Machinery and Equipment Appraisal Accreditation Course, parts 1\&2, 2019.

4. Mathematical Indices: Available from http://m/youtube.com.watch.

\section{Suplementary Exercise On Trending With Indexes \\ Exercise 1}

Twelve years ago, a client purchased a new x-ray machine for $\$ 25,000$ installed. Since then the manufacturer has serviced the machine in accordance with all maintenance recommendations, and the normal useful life of the machine is 12 years. Using the sample indexes below, what is the estimated cost to replace this machine today? What would the cost have been three years ago? What would the cost have been six years ago? (Carry all index factors out to four decimal places, rounded.)

\section{Sample Equipment Indexes}

\begin{tabular}{|c|c|c|c|c|c|c|}
\hline Age & 50 Industry Average & Metalworking & $\begin{array}{l}\text { Machine } \\
\text { Shop }\end{array}$ & $\begin{array}{l}\text { Office } \\
\text { Equip }\end{array}$ & $\begin{array}{c}\text { Electrical } \\
\text { Equip }\end{array}$ & $\begin{array}{c}\text { Medical } \\
\text { Equip }\end{array}$ \\
\hline 15years ago, & 580 & 700 & 735 & 500 & 630 & 715 \\
\hline 14years ago, & 640 & 770 & 810 & 555 & 700 & 785 \\
\hline 13 years ago & 670 & 805 & 845 & 575 & 720 & 820 \\
\hline 12years ago & 680 & 825 & 865 & 590 & 720 & 840 \\
\hline 11years ago & 700 & 845 & 890 & 600 & 750 & 860 \\
\hline 10years ago & 710 & 860 & 900 & 615 & 755 & 880 \\
\hline 9 years ago & 715 & 870 & 915 & 620 & 760 & 885 \\
\hline 8 years ago & 730 & 880 & 925 & 630 & 770 & 900 \\
\hline 7years ago & 760 & 915 & 960 & 660 & 815 & 935 \\
\hline 6years ago & 800 & 960 & 1,000 & 690 & 860 & 980 \\
\hline 5years ago & 820 & 990 & 1,040 & 710 & 875 & 1,010 \\
\hline 4years ago & 835 & 1,010 & 1,050 & 720 & 880 & 1,030 \\
\hline 3years ago & 845 & 1,015 & 1,065 & 725 & 890 & 1,035 \\
\hline 2 years ago & 860 & 1,030 & 1,080 & 735 & 900 & 1,050 \\
\hline 1year ago & 890 & 1,060 & 1,115 & 750 & 920 & 1,080 \\
\hline Current & 930 & 1,120 & 1,180 & 800 & 975 & 1,140 \\
\hline
\end{tabular}

Note: The above numbers are hypothetical for teaching purposes only.

Solution Exercise 1:

$\mathrm{X}$-ray machine is a medical equipment.

Trend factor $=1140 / 840=i .3571(12$ years life $)$.

Current cost $=1.3571 \times 25000=\$ 33928.57$

Trend factor $=1035 / 840=1.2321(3$ years ago $)$.

Current cost $=1.2321 \times 25000=\$ 30803.57$.

Trend factor $=980 / 840=1.1667$ (6 years ago) .

Current cost $=1.1667 \times 25000=\$ 291667.67$. 


\section{Exercise 2}

Using the sample indexes above, develop trend factors (4 decimal places) and apply to the historical costs. (Use two decimal places for the trended cost.)

\begin{tabular}{|c|c|c|c|}
\hline Item & $\begin{array}{l}\text { Historical Cost } \\
\text { New and Age }\end{array}$ & $\begin{array}{l}\text { Trended } \\
\text { Factor }\end{array}$ & Trended Cost \\
\hline Uncoiler, McKay, 15-hp motor, 50,000-pound capacity & $\begin{array}{l}15 \text { years ago } \\
\$ 18,500\end{array}$ & & \\
\hline a. Machine shop/50 Industry Average & $1180 / 735$ & 1.6054 & 29699.90 \\
\hline $\begin{array}{l}\text { Entrance pinch roll, McKay, } \\
20 " \text { diameter x } 88 \text { " long, 15-hp gear motor }\end{array}$ & $\begin{array}{l}10 \text { years ago } \\
\$ 62,500\end{array}$ & & \\
\hline b. Machine shop/50 Industry Average & $1180 / 900$ & 1.3111 & 81943.75 \\
\hline $\begin{array}{l}\text { Leveler, Bliss, with } 11 " \text { - } 12 " \\
\text { diameter rolls, 100-hp DC motor }\end{array}$ & $\begin{array}{l}12 \text { years ago } \\
\$ 48,500\end{array}$ & & \\
\hline c. 50 Industry Average/Machine shop & $930 / 680$ & 1.3676 & 66328.60 \\
\hline $\begin{array}{l}\text { Side trimmer and scrap } \\
\text { chopper, Bliss, 72" maximum } \\
\text { capacity, 60-hp DC motor }\end{array}$ & $\begin{array}{l}13 \text { years ago } \\
\$ 75,000\end{array}$ & & \\
\hline d. Metalworking/50 Industry Average & $1120 / 805$ & 1.3913 & 104347.50 \\
\hline $\begin{array}{l}\text { Scrap conveyor, Bliss, steel } \\
\text { frame, } 36 " \times 100 " \text { steel mesh belt, } 15 \text {-hp motor }\end{array}$ & $\begin{array}{l}14 \text { years ago } \\
\$ 20,000\end{array}$ & & \\
\hline e. Metalworking/ Machine shop & $1120 / 770$ & 1.4545 & 29090.00 \\
\hline $\begin{array}{l}\text { Lab oven, solar model XK4- } \\
3000, \text { SN } 1796541\end{array}$ & $\begin{array}{l}14 \text { years ago } \\
\$ 1,400\end{array}$ & & \\
\hline f. Medical equipment & $1140 / 785$ & 1.4522 & 2033.08 \\
\hline $\begin{array}{l}\text { Microscope, B\&H model } \\
200 \times 5, \text { SN } 79384\end{array}$ & $\begin{array}{l}12 \text { years ago } \\
\$ 350\end{array}$ & & \\
\hline g. Medical equipment & $1140 / 840$ & 1.3571 & 474.99 \\
\hline $\begin{array}{l}\text { Forklift, Datsun, model M4000, } \\
\text { SN5543 }\end{array}$ & $\begin{array}{l}10 \text { years ago } \\
\$ 7,275\end{array}$ & & \\
\hline h. $\quad 50$ Industry Average/Machine shop & $930 / 710$ & 1.3099 & 9529.52 \\
\hline $\begin{array}{l}\text { Computer, IBM, model XT, SN } \\
62351\end{array}$ & $\begin{array}{l}8 \text { years ago } \\
\$ 2,800\end{array}$ & & \\
\hline i. Office equipment & $800 / 630$ & 1.2698 & 3555.44 \\
\hline $\begin{array}{l}\text { Calculator, Olivetti, Divisuma, } \\
\text { model D-24, SN } 16398\end{array}$ & $\begin{array}{l}11 \text { years ago, } \\
\$ 330\end{array}$ & & \\
\hline j. $\quad$ Office equipment & $800 / 600$ & 1.3333 & 439.99 \\
\hline Progressive die, shop built & $\begin{array}{l}5 \text { years ago } \\
\$ 6,800\end{array}$ & & \\
\hline k. Metalworking/ Machine shop & $1120 / 990$ & 1.1313 & 7692.84 \\
\hline $\begin{array}{l}\text { Desk, wood, exec. Double } \\
\text { pedestal } 84 " \text { × } 36 "\end{array}$ & $\begin{array}{l}7 \text { years ago } \\
\$ 3,765\end{array}$ & & \\
\hline 1. Office equipment & $800 / 660$ & 1.2121 & 4563.56 \\
\hline $\begin{array}{l}550 \text { linear } \mathrm{ft} \text {, stainless steel } \\
\text { process piping }\end{array}$ & $\begin{array}{l}10 \text { years ago } \\
\$ 5,500\end{array}$ & & \\
\hline m. 50 Industry Average/Machine shop & $930 / 710$ & 1.3099 & 7204.45 \\
\hline $\begin{array}{l}\text { Electrical distribution panel, } \\
\text { 1,200 amp. W/12 20-amp switches, 1-600 amp main } \\
\text { switch. n. (Electrical equipment) }\end{array}$ & $\begin{array}{l}15 \text { years ago } \\
\$ 3,700 \\
975 / 630\end{array}$ & 1.5476 & 5726,12 \\
\hline
\end{tabular}

Note: The above costs are hypothetical for teaching purposes only. 